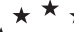

$\star$ Polityki Europejskie.

$\star$ Finanse i Marketing

$\star \star \star \quad 17(66) 2017$

Dorota Jegorow

Katolicki Uniwersytet Lubelski Jana Pawla II

\title{
Źródla finansowania projektów europejskich w wymiarze transferów finansowych Polska - Unia Europejska
}

\section{SOURCES OF FINANCING EUROPEAN PROJECTS IN RELATION TO FINANCIAL TRANSFERS POLAND - EUROPEAN UNION}

\begin{abstract}
Celem niniejszego opracowania jest prezentacja rzeczywistego udziału dofinansowania zagranicznego projektów realizowanych pod szyldem funduszy europejskich, a zatem ze środków pochodzacych ze źródet bezzwrotnych w okresie od maja 2004 r. do lutego 2017 r. Przeprowadzona analiza ocharakterze ilościowo-jakościowym uwzględnia poziom dofinansowania tzw. projektów europejskich $w$ wymiarze źródel pochodzenia dotacji $z$ uwzględnieniem transferów finansowych pomiędzy budżetami Polski i Unii Europejskiej. Ogót danych ilościowych poddanych relatywnej analizie statystycznej pochodzi ze zbiorów publicznych oraz dokumentów programowych zwiqzanych z politykq regionalnq. Kontekst jakościowy analizy wpisany zostat w literaturowe studia porównawcze.
\end{abstract}

Słowa kluczowe: fundusze europejskie, polityka spójności, rozwój regionalny, Unia Europejska, zróżnicowanie regionalne.

\section{Wprowadzenie}

Polska przystępując do wspólnoty państw członkowskich Unii Europejskiej włączyła się $\mathrm{w}$ realizację potężnego ponadnarodowego projektu, w którym jednym z kluczowych instrumentów w wymiarze ekonomicznym stały się fundusze pomocowe. W praktyce, $\mathrm{w}$ okresie kilkunastu minionych lat, funkcjonowanie polskiej gospodarki zostało wkomponowane $\mathrm{w}$ złożony system dotacji. Proces ten zapoczątkowany został możliwością korzystania $z$ funduszy przedakcesyjnych, a od maja 2004 r. funduszy dedykowanych państwom członkowskim Unii Europejskiej. Podmioty gospodarki narodowej wywodzące się $\mathrm{z}$ sektora publicznego i prywatnego niemal na równi podejmują się nie lada trudu aplikacyjnego. Nie chodzi w tym miejscu o chęć przejaskrawienia istoty procesu wpisanego $\mathrm{w}$ przygotowanie wniosku o dofinansowanie realizacji projektu i jego złożenie w odpowiedzi na ogłoszony konkurs, ale o realną oceną zdarzenia. W zależności od reprezentowanego sektora problemy pojawiają się na różnych etapach przygotowania projektu i w różnym wymiarze. Ogół inicjatyw łączy jednak olbrzymi trud związany z opracowaniem wniosku, a jednocześnie niepewność, co do otrzymania dotacji, za wyjątkiem projektów pozakonkursowych lub systemowych.

Zamiennie używanym nazwom ,projekty unijne” oraz „projekty europejskie” towarzyszy przekonanie o tym, że podstawowym źródłem finansowania realizowanych przedsięwzięć są fundusze zagraniczne rozłączne z budżetem Polski. Niewątpliwie jest 
to zgodne ze stanem faktycznym, jednak informacje o rzeczywistych proporcjach udziału środków krajowych i zagranicznych są nader często pomijane przy prezentacji projektów. W trosce o należyte i powszechne informowanie ogółu społeczeństwa o źródłach finansowania poszczególnych przedsięwzięć, beneficjenci pomocy zostali zobligowani do stosowania odpowiednich logotypów oraz napisów niemal na każdym wytworzonym w projekcie produkcie. Równolegle jednak, poza tablicami pojawiającymi się przy inwestycjach infrastrukturalnych, pomijana jest informacja o poziomie dofinansowania pochodzącego bezpośrednio z budżetu Unii Europejskiej oraz nie są wskazywane pozostałe źródła finansowania. Prowadzi to do kreowania przekazu, iż ogół projektów to wyłączna zasługa funduszy europejskich mających z krajowym budżetem niewiele wspólnego.

Celem niniejszego opracowania jest prezentacja rzeczywistego udziału dofinansowania projektów realizowanych pod szyldem funduszy europejskich ze środków pochodzących z bezzwrotnych źródeł zagranicznych. W badaniu uwzględniono obowiązkowe składki członkowskie, koszty obsługi realizowanych transferów finansowych, jak również wydatki związane $\mathrm{z}$ obsługą pojedynczych projektów w wymiarze administracyjno-technicznym. Przeprowadzona analiza o charakterze ilościowym uwzględnia poziom dofinansowania projektów europejskich w zakresie źródeł pochodzenia dotacji oraz wysokość transferów finansowych pomiędzy Polską i Unią Europejską. Ogół danych ilościowych poddanych relacyjnej analizie statystycznej pochodzi z baz danych Ministerstwa Rozwoju: Krajowy System Informatyczny SIMIK 07-13, Mapa dotacji Unii Europejskiej, Banku Danych Lokalnych Głównego Urzędu Statystycznego (BDL GUS), sprawozdań Ministerstwa Finansów, bazy danych Komisji Europejskiej oraz dokumentów programowych związanych z polityką regionalną. Kontekst jakościowy analizy wpisany został w literaturowe studia porównawcze.

Teoretyczno-praktyczny charakter opracowania spełnia kryteria poznawcze i aplikacyjne. Identyfikacja aktualnych procesów gospodarczych może być pomocna $\mathrm{w}$ formułowaniu ocen prowadzonej polityki gospodarczej, a w konsekwencji może przyczynić się do podejmowania działań zmierzających do podwyższenia efektywności ekonomicznej inwestycji finansowanych ze środków publicznych. Ważnym wymiarem opracowania jest również walor edukacyjny zorientowany na konieczność rewizji przekazu dotyczącego funduszy europejskich i ich udziału w krajowej gospodarce, jak i w projektach indywidualnych.

\section{(Nie)efektywność funduszy pomocowych Unii Europejskiej - ilość versus jakość}

Potężne środki finansowe wpisane $\mathrm{w}$ budżet Unii Europejskiej połączone $\mathrm{z}$ narracją zorientowaną na niemal naturalny potencjał rozwojowy leżący u ich podstaw sprawiaja, że stają się one realnym obiektem pożądania. Kreowanie świata dobrobytu jest przekazem pozytywnym. Gorzej jest wówczas, gdy okazuje się, że są to złudzenia. Poważny kryzys dotykający dziś Unię Europejską to kryzys wyobraźni. Same pieniądze nie są remedium na piętrzące się problemy. Należy znaleźć nowy sposób dystrybucji środków finansowych (Zielonka, 2014). Pomoc zewnętrzna - tak jak inne czynniki egzogenne może mieć znaczenie prorozwojowe, jednak tylko wówczas, gdy endogenne uwarunkowania pozwolą ją wykorzystać do przyspieszenia zmiany strukturalnej 
(Gorzelak, 2009). Przy braku spójnego programu działań w zakresie polityki regionalnej w Polsce (Kudełko, 2014) warunek konieczny efektywnego rozwoju nie jest spełniony. Za wieloma inwestycjami realizowanymi przy wsparciu funduszy europejskich kryje się racjonalność biurokratyczna i populistyczna, ale rzadko rozwojowa. Wprawdzie równowaga suboptymalna jest zachowana, ale jednocześnie zręczne grupy interesu w sposób pasożytniczy władczo przechwytują dostęne zasoby (Zybertowicz i in., 2015). Nie można zaprzeczać, że strumień finansowy płynie do Polski wartkim nurtem, jednak czerpią z niego nieliczni, a jego praktyczna obsługa generuje wysokie koszty.

Krytyczne opinie dotyczące polityki regionalnej realizowanej przy wsparciu funduszy europejskich mają swoje podłoże w rozpoznaniu wielu z przyjętych w Polsce rozwiązaniach atrapy rozwoju (Kozak, 2015). Wśród krytycznych uwag dominuje pogląd, że fundusze europejskie będące podstawowym narzędziem polityki spójności wykorzystywane są głównie na cele konsumpcyjnie, często wręcz marnotrawione, a przez to nie mają większego wpływu na niwelowanie różnic rozwojowych między regionami (Pastuszka, 2012). Pożądana konwergencja zatem nie następuje, a jednocześnie nasila się dywergencja regionalna i wewnątrzregionalna (Kozak, 2014). Różnice rozwoje, zamiast maleć systematycznie się pogłębiają. Dowody empiryczne wpisane $w$ analizy naukowe wskazują, że fundusze europejskie nie mają z jednej strony wpływu na powstawanie nowych miejsc pracy, a z drugiej strony wręcz niszczą innowacyjność gospodarki (Rybiński, 2014). Fundusze europejskie porównuje się ze „ś́wiatem niezwykłej ułudy”, wskazując jednocześnie na „ułudę racjonalnego rozwoju” (Zybertowicz, Gurtowski i Sojak, 2015, s. 85, 100).

Wysokie środki finansowe redystrybuowane w stworzonym systemie projektów wpisane są w skomplikowane procesy aplikacyjne. Problem polega jednak na tym, że stworzony system ewaluacji nie pozwala na uchwycenie realnych efektów przedsiębranych działań, a prowadzi nader często do absurdalnej kwantyfikacji. W tak stworzonym systemie sprawozdawczym i oceniającym jakość i efekt prorozwojowy nabierają drugorzędnego znaczenia (Jegorow, 2016a). Prowadzona ewaluacja systemu wsparcia jest punktowa zarówno w wymiarze problematyki badawczej, jak i relacji w ujęciu dynamicznym, co w efekcie marginalizuje fakt, że podczas realizacji projektów dochodzi do zastępstwa celów. Zamiast skupiać się na efektach podejmowanych działań istotę rozwoju nader często sprowadza się wyłącznie do poziomu wydatkowanych funduszy. Sytuacja ta jest dowodem orientacji na środki działania i mylenie ich z celami oraz ewidentny brak wizji integracji procesów rozwojowych (Woźniak, 2014). System monitorowania realizowanych projektów choć oparty jest na rozbudowanym układzie wskaźników, to ich istota i zakres w praktyce podważają możliwość jakiekolwiek syntezy (Szlachta, 2010). „Stawianie zatem na ilość pozyskanych funduszy, określane tzw. „wyciskaniem brukselki” lub „opium absorpcji”, obawa, aby przypadkiem nie oddać Brukseli ani jednego euro dotacji i premiowanie beneficjentów, będących liderami „przerobu” szybko może okazać się myśleniem antyrozwojowym” (Słodowa-Hełpa, 2013, s. 202).

Oczywiście potencjalne korzyści z transferów unijnych nie mogą sprowadzać się wyłącznie do dodatkowych strumieni środków finansowych, ale winny obejmować również inne efekty, w tym mobilizowanie wyższych środków finansowych (w ramach współfinansowania), synergię oraz wzmocnienie przedsiębiorczości (KaweckaWyrzykowska, 2010). Okazuje się jednak, że wysokiej absorpcji funduszy pomocowych 
w minionej dekadzie towarzyszyło systematyczne zadłużanie się sektora finansów publicznych i to głównie za sprawą wnoszenia obowiązkowych wkładów własnych w realizowanych projektach europejskich. Ponadto wiele projektów zrealizowanych zostało z wbrew logice inwestycji strategicznych, nie w odpowiedzi na realne potrzeby, ale z uwagi na możliwość pozyskania środków (Jegorow, 2016b). Z kolei przedsiębiorcy zamiast reagować na potrzeby konsumentów walczą o dotacje, a ich działania przypominają zachowania socjalistycznych zakładów pracy. Dotacje stają się ,dobrem deficytowym", a ich niedobór jest stanem permanentnym (Jakimowicz, 2012).

Nie można nie dostrzegać faktu, iż w obszarze funduszy europejskich marginalizuje się rolę nauki, a gremia eksperckie zastępuje się komisjami złożonymi z urzędników państwowych. A to w opinii przedstawicieli świata nauki jest fikcją i farsą (Kieżun, 2013). Z punktu widzenia strategicznych korzyści rozwojowych można mieć poważne wątpliwości, co do efektywności obowiązujących mechanizmów finansowania i rzeczywistego wkładu funduszy europejskich $\mathrm{w}$ przedsięwzięcia podejmowane $\mathrm{w}$ Polsce. Prowadzenie badań empirycznych w zakresie pomiaru efektywności działań realizowanych dzięki funduszom pomocowym jest niezbędne w obliczu szeregu przywołanych wyżej krytycznych ocen. Istniejące mechanizmy oparte na procedurach administracyjnych nie sprawdzają się. Rażące dysproporcje życia, pracy i płacy obywateli wspólnoty są tego dowodem. Prymat polityki nad ekonomią również jest poważnym problemem zawiązanego bloku państw. Empirycznym dowodem kryzysu współczesnej Unii Europejskiej jest Brexit.

\section{Transfery finansowe budżetów Polska - Unia Europejska}

Począwszy od 1 maja 2004 r. do końca lutego 2017 r. saldo transferów finansowych pomiędzy budżetami Polski i Unii Europejskiej to kwota przekraczająca 91 mld EUR na korzyść Polski. Transferom z Unii Europejskiej do Polski na kwotę przekraczająca 135 mld EUR odpowiada ponad 44 mld EUR wpłat do budżetu Unii Europejskiej (Ministerstwo Finansów, 2017). Przepływy finansowe kierowane do budżetu Unii Europejskiej obejmują zarówno składkę członkowska, jak i zwroty, które w kwocie przekraczającej dotychczas $152 \mathrm{mln}$ EUR stanowią nieznacznie powyżej $0,34 \%$ wpłat. Najwyższe wpływy finansowe do budżetu Polski z budżetu Unii Europejskiej zanotowane zostały w roku 2014 po systematycznym wzroście począwszy od roku 2004. Lata 2015-2016 charakteryzowały się tendencją wprost przeciwną. Niewątpliwie fakt ten należy łączyć z przejściem pomiędzy kolejnymi perspektywami finansowymi, jak również zmianami na polskiej scenie politycznej dotykającymi m.in. instytucję zarządzającą funduszami europejskimi jaką jest Ministerstwo Rozwoju. 


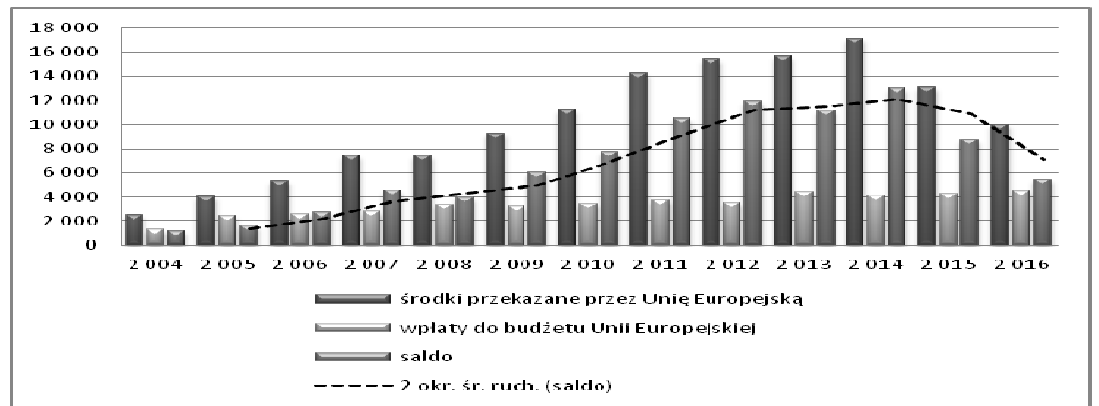

Rysunek 1. Skumulowane transfery finansowe między Polską a Unią Europejską w latach 2004-2016 [w mln EUR].

Źródło: opracowanie w własne na podstawie danych MF.

W praktyce Polska dokonywanymi wpłatami pokrywa prawie 32\% transferów z budżetu Unii Europejskiej. Biorąc pod uwagę okres wzajemnych zobowiązań finansowych okazuje się, że przeciętnie rocznie do Polski trafia niewiele ponad 6,8 mld EUR. Biorąc z kolei pod uwagę liczbę mieszkańców Polski, która wg danych GUS wynosi prawie 38,5 mln osób okazuje się, że na jednego obywatela rocznie przypada nieznacznie powyżej 177 EUR środków zagranicznych, pomimo wysokości dotacji kształtującej się na poziomie prawie 265 EUR. Niewątpliwie otrzymany wynik rzuca niekorzystne światło na nadmierną ekscytację strumieniem funduszy europejskich skierowanych do Polski. Realny związek dotacji pochodzących z Unii Europejskiej $\mathrm{z}$ polską gospodarką istotnie zatem rozmywa się. Często powielany w przestrzeni publicznej przekaz, iż to Polska jest największym beneficjentem funduszy europejskiej jest prawdą. Rzetelność sprawozdawcza wymaga jednak relatywizmu dającego podstawy do formułowania obiektywnych wniosków.

Ponad 96\% środków trafiających z budżetu Unii Europejskiej do Polski przeznaczanych jest na realizację projektów w obszarze polityki spójności $(62 \%)$ i wspólnej polityki rolnej (34\%). Okazuje się zatem, że szacunkowa wartość projektów realizowanych w ramach środków Funduszu Spójności i funduszy strukturalnych, tj. Europejskiego Funduszu Społecznego i Europejskiego Funduszu Rozwoju Regionalnego w przeliczeniu na jednego mieszkańca Polski w ujęciu rocznym wynosi niespełna 254 EUR (jako wynik transferów jednostronnych). Biorąc pod uwagę saldo wzajemnych rozliczeń wskaźnik ten należy szacować na poziomie niespełna 170 EUR.

Należy jednocześnie pamiętać, że w obsługę administracyjną całego systemu programowania, wdrażania i kontroli projektów współfinansowanych $\mathrm{z}$ funduszy europejskich zaangażowane zostały bardzo duże zasoby kadrowe finansowe $\mathrm{z}$ tej samej puli środków w szczególności w ramach pomocy technicznej. W praktyce zatem mówiąc o kwocie 177 EUR rocznie na mieszkańca Polski należy brać pod uwagę również koszty związane $\mathrm{z}$ rozbudowaną obsługą administracyjną wpisaną $\mathrm{w}$ praktykę realizacji projektów. Odrębną kwestią jest bezpośrednia obsługa projektów w zakresie kosztów pośrednich i zarządzania. Niejednokrotnie są to koszty kształtujące się na poziomie przekraczającym $40 \%$ wartości projektu w przedsięwzięciach o niskiej alokacji. Z kolei w projektach wysokobudżetowych niezwykle ważną kwestią jest udział wykonawców zadań zleconych będących przedsiębiorcami krajowymi. Chodzi o wpływy do budżetu 
państwa związane $\mathrm{z}$ regulowaniem należności podatkowych, obowiązkami prawnofinansowymi związanymi $\mathrm{z}$ zatrudnieniem personelu projektowego, jak również ponoszenia kosztów pośrednich wynikających $\mathrm{z}$ faktu prowadzenia działalności gospodarczej.

Wieloletnie ramy finansowe 2014-2020 zaprogramowane kilka lat temu z założenia mają być ostatnimi przynoszącymi dodatnie saldo transferowe dla Polski. Zapowiadana kwota 89 mld EUR funduszy europejskich przeznaczona dla Polski, z ogólnej puli 450 mld EUR (Komisja Europejska, 2015), jest największa spośród ogółu państw członkowskich Unii Europejskiej. Biorąc jednak pod uwagę liczbę mieszkańców Polski planowany strumień finansowy w przeliczeniu na jednego mieszkańca plasuje się na poziomie 2,3 tys. EUR, tym samym jest znacznie niższy od chociażby wskaźnika Estonii przekraczającego 3,5 tys. EUR. W szczególności z puli 350 mld EUR zaplanowanych na politykę spójności do Polski powinno wpłynąć 77,5 mld EUR (European Commission, 2015), tj. 2 tys. EUR na osobę, a w ujęciu rocznym niespełna 289 EUR (wg komunikatu Ministerstwa Infrastruktury i Rozwoju z dn. z dnia 26 lutego 2015 r., jest to kwora nieco inna, tj. 82,5 mld EUR). Zakładając, iż składki członkowskie wpisane $\mathrm{w}$ transfery finansowe pomiędzy budżetami Polski i UE pozostaną na poziomie $32 \%$ puli otrzymanych środków, przekazane do dyspozycji fundusze w ramach inicjatyw projektowych pozostaną na zbliżonym poziomie do obecnego.

Analiza ilościowa wprawdzie nie uwzględnia kontekstu jakościowego realizowanych projektów, nie oznacza to jednak, że można ten wymiar pomijać. Niezwykle cennym źródłem wiedzy mogłyby być w tym przypadku konkretne projekty, zapisane $\mathrm{w}$ nich zadania służące realizacji określonych celów łącznie $\mathrm{z}$ montażem finansowym. Wynika to $\mathrm{z}$ faktu, że pomimo szerokiej i niewatpliwie kosztownej promocji przedsięwzięć realizowanych przy współudziale funduszy europejskich ocena ex post wielu zrealizowanych już przedsięwzięć jest negatywna zarówno w wymiarze zasadności, jak i efektywności podejmowanych działań w kontekście prorozwojowym. Nie brakuje bowiem przykładów projektów nieprzemyślanych, zbędnych, a w skrajnych przypadkach dodatkowo obciążających firanowo podatników nie przedstawiając jednocześnie żadnej wartości.

\section{Wartość projektów europejskich a poziom dofinansowania zagranicznego w ramach polityki spójności Unii Europejskiej}

Największy udział w strukturze przepływów finansowych budżetów Unia Europejska Polska przypada na politykę spójności - ponad $62,2 \%$. I to właśnie ten instrument wsparcia $\mathrm{w}$ największym wymiarze jest obecny $\mathrm{w}$ przestrzeni publicznej, a to przede wszystkim poprzez realizację projektów w ramach funduszy strukturalnych na które przypada prawie 40,8\% transferów. Prezentowany przez Ministerstwo Rozwoju w „Mapie Dotacji UE” wykaz projektów zrealizowanych w perspektywach finansowych 2004-2006 i 2007-2013 w ramach polityki spójności zwraca imponującą bazę inicjatyw o wartości przekraczającej 603 mld PLN, przy dofinansowaniu pochodzącym z funduszy europejskich nieznacznie przekraczającym 333 mld PLN (transfery w kwocie nieznacznie przekraczającej 75 mld EUR). Tym samym rzeczywisty udział dofinansowania $\mathrm{z}$ budżetu Unii Europejskiej ogółu projektów sprowadza się do poziomu niespełna 55,3\%. Biorąc pod uwagę wzajemne transfery finansowe budżetów Polski i 
Unii Europejskiej, wyznaczone saldem dokonywanych operacji, powyższy wynik należy obniżyć do poziomu niespełna 37,2\%. Należy każdorazowo brać pod uwagę fakt, że w pozycji dofinansowanie pochodzące z budżetu Unii Europejskiej mieszczą się publiczne środki krajowe $\mathrm{i}$ to $\mathrm{w}$ relatywnie wysokim udziale. Oszacowany niski poziom dofinansowania zagranicznego projektu nie oznacza zatem konieczności wnoszenia wkładu własnego, bo $\mathrm{z}$ założenia środki finansowe przeznaczone na programy pomocowe łączą fundusze europejskie ze środkami pochodzącymi z budżetu państwa. A zatem projekt realizowany $\mathrm{w}$ ramach otrzymanej dotacji pokrywającej $100 \%$ kosztów kwalifikowalnych w praktyce podlega współfinansowaniu ze środków pochodzących z budżetu państwa i funduszy europejskich. Niższy poziom dofinansowania w odniesieniu do założonej wartości projektu związany jest $\mathrm{z}$ koniecznością wnoszenia wkładu własnego $\mathrm{w}$ formie finansowej, rzeczowej lub wolontarystycznej. Praktyka ta uwzględnia zróżnicowane poziomy obligatoryjnej partycypacji w pozycjach kosztowych w zależności od rodzaju projektu i województwa na terenie którego przedsięwzięcie jest realizowane.

Wobec powyższych danych dominujący w przestrzeni publicznej przekaz o pochodzeniu funduszy europejskich, jako zewnętrznych wobec polskiej gospodarki, niewątpliwie może wprowadzać w błąd. Należy w tym miejscu po raz kolejny zaznaczyć, że zaprezentowane szacunki nie uwzględniają kosztów zarządzania i obsługi administracyjnej ogółu przedsięwzięć wpisanych w fundusze europejskie zarówno od strony instytucji zarządzającej, pośredniczącej, wdrażającej, jak i samych beneficjentów - projektodawców. W praktyce są to jednak wydatki znaczące. Zaprezentowana analiza nie uwzględnia również kosztów przygotowywania wniosków aplikacyjnych, jak również sporządzania pełnej dokumentacji wymaganej procedurą przed podpisaniem umowy o dofinansowanie. $W$ niektórych konkursach koszty te można zaliczać do wydatków projektowych, a w innych nie, jak miało to miejsce w Programie Operacyjnym Kapitał Ludzki 2007-2013. W praktyce brak możliwości pokrycia takiego wydatku z otrzymanej dotacji nie jest tożsamy z działalnością bezkosztową. Instytucje publiczne, a w szczególności te wpisane w strukturę administracyjną utworzyły liczne nowe stanowiska pracy związane $\mathrm{z}$ pozyskiwaniem i rozliczaniem dotacji, $\mathrm{w}$ tym zwłaszcza tych pochodzących $\mathrm{z}$ funduszy europejskich. Kwestia finansowania tych stanowisk wpisana została $\mathrm{w}$ ogół bieżących wydatków jednostek budżetowych. Z kolei w sektorze prywatnym wydatki te nie zawsze są wykazywane, chociaż są ponoszone. Niezależnie od niuansów stosowanych rozwiązań koszt pozyskania dotacji w praktyce zmniejsza realną wartość dofinansowania.

Prezentowane powyżej wyniki są zarówno twardymi wskaźnikami, jak i szacunkami. Odrębną, choć istotną kwestią w przeprowadzonej analizie jest kompletność danych obrazujących rzeczywiste wartości kosztowe realizowanych projektów. Niestety BDL GUS zwraca dane wyłącznie odnoszące się do wieloletnich ram finansowych 2007-2013, podobnie jak nowy moduł analityczny STRATEG GUS tzw. „System monitorowania rozwoju” zresztą nieprecyzyjny i pełen błędów. Aplikacja ta powstała $\mathrm{w}$ ramach projektu współfinansowanego $\mathrm{z}$ funduszy europejskich. Niefrasobliwość w obszarze gromadzenia i systematyzowania danych odnoszących się do funduszy europejskich jest niezrozumiała. Wysoce pożądane jest precyzyjnie uzupełnienie i jednoznaczne rozdzielenie danych wg poszczególnych wieloletnich ram finansowych. Poza problem z dostępem do danych, ich niekompletnością, jest brak 
poprawnej terminologii, co jest jednoznacznym wyrazem bylejakości, a jednocześnie może wprowadzać w błąd. Trudno zatem oczekiwać rzetelnych analiz sprawozdawczych w zakresie ewaluacji funduszy pomocowych, skro problemy pojawiają się na etapie gromadzenia danych ilościowych.

\section{Zakończenie}

Już prawie trzynastoletni okres czynnego włączenia się Polski w udział w projekt, jakim jest Unia Europejska, to moment w którym nie można mówić o eksperymencie. Zasady wpisane w pobór i podział funduszy europejskich to ściśle sprecyzowany mechanizm tworzący w Polsce rozbudowaną i ukrystalizowaną strukturę. Jednak środki finansowe pochodzące z puli funduszy europejskich, będące kluczowym narzędziem w aktywności gospodarczej, podlegają skrajnie odmiennym opiniom. Kreowaniu bezprecedensowej mocy sprawczej funduszy europejskich samych w sobie przeciwstawiane są liczne dowody empiryczne na wyrafinowany cynizm tego poglądu. Po pierwsze nader często pomijany jest realny koszt otrzymania dotacji wpisany zarówno w obligatoryjne daniny, obsługę administracyjną i zarządczą oraz, co nie wpisuje się bezpośrednio $\mathrm{w}$ analizy ilościowe, niewspółmierne z korzyściami w wielu przypadkach ryzyko oraz degradację oddolnej przedsiębiorczości. Fundusze kierowane do projektodawców, które z założenia miały być niejako pomocą zagraniczna, w praktyce w znaczącym zakresie pokrywane są z krajowych środków publicznych lub pieniędzy prywatnych. Świadomość ta nie towarzyszy jednak przy realizacji wielu projektów. Wszechobecne logotypy z symboliką ściśle określoną przez instytucje Unii Europejskiej pojawiające się na tablicach przy drogach, budynkach, boiskach, lotniskach, jak również na książkach, kubkach, długopisach itp., powodują budowanie jednoznacznego przekazu o tym, że fundatorem ogółu oznakowanych dóbr i usług jest Unia Europejska. Oczywiście nie można marginalizować korzyści Polski zakcesji do Unii Europejskiej i realnych kwot transferowanych do Polski, należy jednak uczciwie bilansować wzajemne transfery. Percepcja społeczna sprowadzająca funkcjonowanie Polski we wspólnocie europejskiej niemal wyłącznie do możliwości korzystania $\mathrm{z}$ funduszy pomocowych bez dostrzegania innych korzyści (Jegorow, 2017) jest poważnym wyzwaniem edukacyjnym.

Presja czasowa na wydawanie funduszy europejskich oraz skomplikowane mechanizmy obowiązujące $\mathrm{w}$ tym zakresie sprawiaja, że nader często w wielu przypadkach kwoty wydanych środków są mylone $\mathrm{z}$ celami działania. Budowanie świadomości, że tzw. projekty unijne $\mathrm{w}$ większości finansowane są ze środków krajowych jest zatem niezbędne. Działania w tym zakresie są szczególnie ważne w kontekście wieloletnich ram finansowych 2014-2020, tak by dbałość o efekty realizowanych projektów nie została przesłonięta brakiem świadomości o rzeczywistym źródle finansowania. Przekaz dotyczący jednostronnych transferów finansowych z UE do Polski, wobec rzeczywistych kosztów związanych ze zobowiązaniami finansowymi państw członkowskich UE do budżetu wspólnoty oraz kosztów technicznej realizacji projektów, nie może być pomijany $w$ analizach zarówno ilościowych, jak i jakościowych. Transparentność programowania rozwoju wpisana w polityki rozwojowe Unii Europejskiej w świetle powyższych danych należy ocenić jako wysoce wątpliwą. 


\section{Bibliografia}

European Commission: European Structural and Investment Funds. Data, https://cohesiondata.ec.europa.eu/dataset/Total-EU-Allocations-Per-MS-Transposed-2014-2020/ncu7-hucf, dostęp: 23.10.2016.

Gorzelak, G.: Fakty i mity rozwoju regionalnego, Studia Regionalne i Lokalne nr 2 (36), 2009, s. 5-27.

Jakimowicz A.: Podstawy interwencjonizmu państwowego, Wydawnictwo Naukowe PWN, Warszawa 2012

Jegorow D.: Ewaluacja polityki spójności: ilość versus jakość, Studia i Prace WNEiZ US, Nr 46/2 2016, s. 255-264.

Jegorow D.: Obniżenie zdolności do generowania dochodów własnych województw - bariera w absorpcji funduszy europejskich, Nierówności Społeczne a Wzrost Gospodarczy, nr 48 (z. 4), 2016, s. 301-311.

Jegorow D.: Poglądy studentów ekonomii na wpływ członkostwa w Unii Europejskiej na polską gospodarkę, [w:] Prawno-ekonomiczne szanse i bariery rozwoju przedsiębiorczości w Polsce i Europie, M. Stefański (red.), Wyższa Szkoła Ekonomii i Innowacji w Lublinie, Lublin 2017, s. 719.

Kawecka-Wyrzykowska E.: Przepływy finansowe między Polską a budżetem Unii Europejskiej efekty okresu akcesji i możliwe zmiany, Problemy zarządzania, vol. 8, nr 1 (27), 2010, s. 57-75.

Kieżun W.: Patologia transformacji, Wydawnictwo Poltext, Warszawa 2013.

Komisja Europejska: Alokacje finansowe 2014-2020, http://ec.europa.eu/regional_policy/sources/what/future/xls/overall_table.xls, dostęp: 21.10.2016.

Kozak M.W.: Co wymyśli chodnik, czyli polska atrapa rozwoju (rozmowa G. Sroczyńskiego), art. $z$ dn. 30.05.2015,

http://wyborcza.pl/magazyn/1,145247,18019268,Co_wymysli_chodnik_czyli_polska_atrapa_roz woju.html, dostęp: 22.12.2016.

Kozak M.W.: Konflikty wokół nowego paradygmatu a rozwój regionalny Polski po 1990 roku, Nierówności Społeczne a Wzrost Gospodarczy nr 37 (z. 1), 2014, s. 163-180.

Kudełko J.: Uwarunkowania rozwoju regionalnego w świetle założeń europejskiej polityki spójności na lata 2014-2020, Studia Ekonomiczne nr 166, 2014, s. 118-127.

Ministerstwo Finansów: Transfery finansowe Polska - Unia Europejska. http://www.mf.gov.pl/ministerstwo-finansow/dzialalnosc/unia-europejska/transfery-finansowepolska-ue, dostęp: 12.04.2017.

Ministerstwo Infrastruktury i Rozwoju: Start Funduszy Europejskich 2014-2020 - miliardy na rozwój, https://www.funduszeeuropejskie.gov.pl/strony/wiadomosci/start-funduszy-europejskich2014-2020-miliardy-na-rozwoj/, dostęp: 28.12.2016.

Ministerstwo Rozwoju: Mapa dotacji UE. http://mapadotacji.gov.pl/, dostęp: 15.09.2016.

Pastuszka S.: Polityka regionalna Unii Europejskiej - cele, narzędzia, efekty, Wydawnictwo Difin, Warszawa 2012.

Rybiński K.: Ekonomia w Matriksie, Wydawnictwo Słowa i Myśli, Lublin 2014.

Słodowa-Hełpa M.: Rozwój zintegrowany. Warunki, wymiary, wyzwania, Wydawnictwo CeDeWu Warszawa 2013.

Szlachta J., Zaleski J.: Kierunki polityki regionalnej w Polsce do roku 2020, Gospodarka Narodowa nr 10, 2010, s. 37-56.

Woźniak M.G.: Rozwój społeczno-ekonomiczny w III Rzeczypospolitej. Efekty. Defekty, Warunki integracji. Nierówności Społeczne a Wzrost Gospodarczy nr 39 (z. 3), 2014, s. 38-54.

Zielonka J.: Koniec Unii Europejskiej? Wydawnictwo Polski Instytut Spraw Międzynarodowych, Warszawa 2014.

Zybertowicz A., Gurtowski M., Sojak R.: Państwo Platformy. Bilans zamknięcia, Wydawnictwo Fronda, Warszawa 2015. 


\section{Summary}

The aim of this study is to present the real financing of projects implemented under the aegis of European funds of funds coming from non-returnable foreign sources in Poland since May 2004 until February 2017. In fact, this level is insignificant. The analysis of quantitative and qualitative takes into account the level of co-financing of European projects in terms of sources of grants and financial transfers between Poland and the European Union.

Key words: EU funding, cohesion policy, regional development, the European Union, regional differentiation.

Informacja o autorze:

\section{dr Dorota Jegorow}

Instytutu Ekonomii i Zarządzania

Katedra Zastosowań Matematyki

Katolicki Uniwersytet Lubelski Jana Pawła II

Al. Racławickie 14; 20-950 Lublin

p. C-528 - Collegium Jana Pawła II

e-mail: dorotajegorow@kul.pl 